Article

\title{
Continuing Trends in Popular Holocaust Fiction: Heather Morris and the Corporealization of Women's Suffering
}

\section{David Dickson}

School of Area Studies, History, Politics and Literature, University of Portsmouth, Portsmouth PO1 3AS, UK; david.dickson86@gmail.com

Received: 14 November 2019; Accepted: 27 December 2019; Published: 31 December 2019

\begin{abstract}
This article explores the problematic representation of female sufferers in works of fiction relating to the Holocaust. Specifically, I contend that modern fiction fails to engage with the moral and emotional complexity of wartime sexual compromise and instead replaces a cognitive understanding of history with a bodily connection to women's wartime pain. I do so by focusing on Heather Morris's two Holocaust-themed texts: The Tattooist of Auschwitz (2018) and Cilka's Journey (2019). Morris, the article contends, cannot connect to the psychological or moral reality of Cilka's wartime abuse and so instead focuses on the corporealization of her suffering. Having established the existence of the trend in Morris's fiction, the article then also addresses Morris's associated need to morally contextualise Cilka's actions. In order to maintain her connection with Cilka's body, I assert, Morris must frame Cilka's actions using the incompatible morality of the post-war present day. To provide the character with depth would block Morris's engagement with Cilka's body as a post-memorial nonwitness. This is profoundly problematic as, rather than informing our understanding of the Holocaust past, Morris merely perpetuates a view of the event that is objectifying, de-humanising and frequently misogynistic.
\end{abstract}

Keywords: Holocaust literature; corporeality; prosthetic memory; Holocaust piety; body; sexual violence

As of 24 October 2019, it was reported that Heather Morris's The Tattooist of Auschwitz sold in excess of one million copies across its various print editions within the UK alone. ${ }^{1}$ At the time of writing, it also occupies the number two position on the Sunday Times bestseller list and has spent over sixty weeks on the New York Times bestseller list—occupying the number one spot as recently as 15 December $2019 .^{2}$ The rights for Morris's text have also, crucially, been purchased by Synchronicity Films, which plans to turn the project into "a multi-part, high-end international drama series" (Cowdrey 2018). In terms of its cultural dissemination, therefore, the reach of Morris's text has been substantial. Not since John Boyne's The Boy in the Striped Pyjamas has a Holocaust text resonated so significantly with the broader public and, correspondingly, posed as substantial a threat to our post-memorial understanding of the Holocaust as an event (Boyne 2008). Focusing specifically on Heather Morris's two recent novels-The Tattooist of Auschwitz (2018) and Cilka's Journey (2019)—-this article explores the problems inherent in Morris's presentation of the Holocaust, focusing particularly on her tendency to overemphasize and excessively corporealize the suffering of the Cilka character. I do so by examining Morris's work in reference to two competing theories of Holocaust engagement: Gillian Rose's theory of Holocaust (Im)Piety and Alison's Landsberg's discussion of "prosthetic memory". Popular Holocaust fiction, I

1 The Booklist asserts that the precise figure is, in fact, 1,006,897 (Mansfield 2019).

2 Sourced from: https://www.nytimes.com/books/best-sellers/2019/12/15/. 
assert, is likely to be both pious in nature and to rely explicitly on prosthetic memory as a means to engage with the Holocaust past.

\section{Background: Rose, Landsberg and Holocaust Kitsch}

Gillian Rose's theory of Holocaust (Im)Piety is concerned, principally, with the concept of psychological proximity to the victims and perpetrators of the Holocaust. Pious texts, she argues, do not seek to capture the psychology or inner motivations of the characters being presented but, instead, opt for a moral simplicity, which allows the reader to maintain a reverential distance from the Holocaust. Using Steven Spielberg's Schindler's List as her test case, she notes that Spielberg's incarnation of Oskar Schindler is not a comprehensibly human character with understandable motivations, but instead, he is presented as a "ludicrous savior on a charger" (Rose 1996, p. 45). Frequently, she argues, popular Holocaust fiction opts for this kind of moral simplicity, this transformation of human characters into simplistic archetypes in order to maintain a position of "ineffability" (p. 43). In short, Rose argues, popular fiction often aims to "mystify" something that it "dare not understand" as it "may be all too understandable, all too consistent with what we are-human, all too human" (p. 43). Implicit in this argument, therefore, is the understanding that the victims and perpetrators of the Holocaust are psychologically approachable - that, with enough of an historical grounding, we may be able to fictionally depict the psychological reality of their experiences. As Sue Vice has noted, "intertextuality" is a "central element in Holocaust fiction" (Vice 2000, p. 161), as writers operating in the present rely on anterior sources-commonly works of survivor writing, victim testimony or wartime diaries-in order to inject their texts with a sense of authenticity. Mathew Boswell then builds on this argument by noting specifically that works of Holocaust Impiety may be approached thanks to the existence of these anterior texts. He discusses "detail after detail" emerging in "testimony, archival footage and historical studies" (Boswell 2012, p. 15). These, he contends, allow modern creators to "take the imaginative leap" (p. 15) of identifying with collaborators and those within the grey zone. Fiction should, therefore, possess the theoretical capacity to provide a unique insight into the Holocaust past, to further elucidate our understanding of both the sufferer and the oppressor. While texts exist that manage to capture the perspective of those within the SS-Jonathan Littell's (2010) The Kindly Ones may be said to offer an impious insight into the mindset of Maximillian Aue-popular fiction frequently fails to capture the psychology of the suffering. This is due, I contend, to a societal compulsion-arguably most evident in Anglo-American approaches to the Holocaust-to focus on the purely physical reality of Holocaust suffering, to approach and even inhabit the body in pain.

Focusing, at least initially, on the role of cinema, Landsberg's theory of prosthetic memory concerns the potential for popular culture to allow a given audience to temporarily experience the perspective of the "cultural, ethnic [or] racial" (Landsberg 2004, p. 2) other. As she puts it, cinema has the capacity to "suture" viewers "into pasts they have not lived" (p. 14), believing that film provides the means to acquire the specific cultural memories of any given group regardless of one's own "skin colour, ethnic background or biology" (p. 2). Specifically, she states that, through the advent of commodified mass media, Holocaust memory does not belong "only to Jews" and that memories of slavery can no longer be said to belong "only to African Americans" (p. 2). Landsberg therefore conceives of prosthetic memory as a means to cross formerly fixed ethnic boundaries to incorporate into our own worldview snippets from the pasts of other peoples. This, she hopes, will come to provide a "powerful corrective to identity politics" (p. 21), helping to bypass the ideological and cultural myopia that can limit our capacity to engage with others unlike ourselves. The "prosthetic" element of this kind of engagement, she asserts, comes from the temporary nature of the experience. By experiencing a brief, powerful moment of trauma-one that does not originate "organically" (p. 26) in our body and yet is "deeply felt" (p. 3) as it provokes a physical response in the form of sympathetic discomfort-Landsberg feels that the viewer is able to touch the experiences of the ethnic other and to come to a more empathetic understanding of their historical pain. Central to Landsberg's theory, therefore, is the understanding that the past is perhaps best engaged with through the body-that, in order to come to a fuller 
understanding of Holocaust history, we cannot simply engage with the material on an intellectual level. Discussing the representation of the Holocaust in a museum setting, she notes the following: "In the case of the Holocaust museum ... the cognitive mode is woefully inadequate. Could there be a linear narrative, a logical formulation that would make the experience of the Holocaust comprehensible?" (p. 131). The information provided within the United States Holocaust Memorial Museum, she argues, cannot allow her to cross the ethnic divide to fully, empathetically engage with the suffering of the Jewish other. In order to experience a sympathetic sense of vulnerability, she must connect with the Holocaust past in a bodily way. She notes that, having passed through the cattle car-having felt the palpable absence of the murdered and her own potential claustrophobia-she was finally able to form a felt connection with the Holocaust past: "This experience shows rather dramatically how the museum's transgression of the traditional exhibiting strategies-its blurring of boundaries between the spectator and the exhibit-might actually make vulnerable the bodies of its spectators ... it speaks to the power of the museum to place its visitors' bodies in a threatening context" (p. 131). As a modern day, post-memorial viewer, Landsberg struggles to connect with the Holocaust past on an emotional level. As Gary Weissman has argued, nonwitnesses frequently struggle with the idea that the Holocaust is both emotionally and temporally remote. Weissman describes the attempt of Martin Lax, the son of a survivor named Michael Lax, to engage with the Mauthausen camp in the present day. Martin, Weissman claims, wished "to become a prisoner", to actually "feel the horror" (Weissman 2004, p. 1) that his father had felt. The "tidy surface" (p. 2) of present day Mauthausen, however, could not possibly hope to convey a sense of the felt reality of Holocaust suffering. In order to finally come close to his father's experiences, to have the Holocaust emotionally come alive for the briefest instant, Martin instead had to imagine scenes of physical suffering. Learning of the "parachuters" (p. 2), the prisoners thrown helplessly to their deaths from the cliff above the Mauthausen camp, Martin finally experiences the emotional connection to the Holocaust he yearned for: "realising his desire to experience what Mauthausen has been for his father" (pp. 3-4). Martin is satisfied, as he has finally been able to connect with the events of the Holocaust on an emotional and bodily level. Crucially, however, he has not connected with his father's experiences. As Weissman notes, his father had never even "set foot in the Mauthausen quarry" (p. 4). Therefore, Martin has not come to an impious understanding of his father's Holocaust past, but rather, he has instead connected with a depersonalized scene of Holocaust suffering. The body in pain has trumped all other concerns, eclipsing his father's particular story. Martin is satisfied, as he feels that he has touched the experiential core of the Holocaust. This prosthetic encounter with Holocaust suffering has therefore helped to combat his feeling of emotional distance from the event. Having satisfied this core concern, Martin then retreats from engaging with his father's experiences. Prosthetic memory has effectively overridden the need for Holocaust Impiety.

Continuing this argument, I contend that popular Holocaust fiction commonly seeks to satisfy the same impulse - that, rather than seeking to engage with the Holocaust impiously, it instead aims to connect with the felt reality of Holocaust suffering. We, as an Anglo-American audience, are not looking to engage with the victims of the Holocaust impiously, but rather, we are looking to form a felt connection with the Holocaust past. A connection that, once again, can only be generated by a prosthetic engagement with the suffering body. Evidence of this can be found in John Boyne's The Boy in the Striped Pyjamas. In both Boyne's text and Mark Herman's film, the audience is primed to engage not with Shmuel — the Jewish child positioned as the ethnic other on the opposite side of a dividing fence- - but rather with Bruno, the white, middle-class German protagonist. This has been done, Landsberg would argue, in order to generate a better sense of prosthetic engagement between the audience and the subject. Media consumers, she asserts, are broadly incapable of "identification across ethnic lines" (Landsberg 2004, p. 124) and so, in order to engage with the horror of the event, they must be presented with a body comparable to their own: "bodies with which they might have a mimetic relationship, bodies that are not always already starved and deformed but are recognizable, even familiar" (p. 124). Prosthetic engagement is therefore conditional upon a number of associated factors. A body cannot, vitally, possess an excess of qualities that make it unlike our own. This pertains 
not simply to physical differences, but also to cultural and psychological particularities, as is evidenced by Boyne's choice of Bruno as his protagonist. As Anne Rothe states, Bruno is not richly characterized but, rather, portrayed as a "mini-Schindler" or "an infantilised version of the good German figure" (Rothe 2011, p. 139). Invoking Rose's previous description of Spielberg's Schindler, Rothe contends that Bruno is a figure lacking psychological depth. He cannot be approached impiously, as he stands simply as a mythic construction. We can easily step into his shoes and inhabit his experiences as, in terms of his characterisation, he is effectively hollow. This becomes particularly relevant at the end of the text as Bruno, along with Shmuel, later dies in the gas chambers of Auschwitz-Birkenau. As Shmuel still represents the ethnic other, however, Boyne and Herman have rehomed Jewish suffering in the white middle-class body. They have, in essence, created a prosthetic memory for death in the gas chamber. The lesson of popular culture, therefore, is twofold: the Jewish other remains fundamentally unreachable, in terms of psychological understanding, and yet, the experiential core of Holocaust suffering can be touched. The Holocaust past can be engaged with, but principally on a bodily level.

Robert Eaglestone further expands on this discussion of The Boy by describing it, ultimately, as a work of Holocaust kitsch. Eaglestone borrows principally from Imre Kertész's description of kitsch, which asserts that a kitsch text is one that is "incapable of understanding or unwilling to understand the organic connection between our own deformed mode of life (whether in the private sphere or on the level of 'civilization' as such) and the very possibility of the Holocaust" (Kertész 2001, p. 270). Therefore, despite its potentially taboo-breaking depictions of graphic violence, Holocaust kitsch as a genre is consistently "pious" (Eaglestone 2017, p. 155). Kitsch texts will always maintain an emotional distance from both the perpetrators and victims of the atrocity. By refusing to make the Holocaust comprehensible, to make a connection between the morality of the camps and our own potential moral compromise in the future, Holocaust kitsch demonstrates a commitment to ineffability. As the vast majority of popular Holocaust texts arguably fall into the category of Holocaust kitsch-the comparative commercial failure of works such as Tim Blake Nelson's The Grey Zone would seem to affirm this point-I contend that prosthetic memory is being cemented as the principle means of engaging with the Holocaust past, at least for those operating outside of Holocaust academia. ${ }^{3}$

This problem is then further intensified when one comes to factor in the degree to which depictions of Holocaust suffering are frequently gendered. As Alvin Rosenfeld has argued, William Styron's Sophie's Choice solidified the cultural trope of the "Mutilated Woman" within Anglo-American Holocaust fiction, as the "abused and broken body" (Rosenfeld 1988, p. 164) of the female sufferer came to stand in as a metonymy for the horrors of the Holocaust. A woman's vulnerability, particularly when attached to the prospect of sexual menace, serves to make the unprecedented crimes of the Holocaust more comprehensible. In actual fact, as Pascale Bos argues, this trope has existed since January of 1943. A letter, concerning the invented deaths of 93 Warsaw "maidens" who chose to commit "suicide by poison" (Bos 2014, p. 62) rather than face prostitution at the hands of the SS, was widely disseminated in both the British and American press. Bos argues the following:

the trope helped to facilitate an understanding of what were in actuality unprecedented and inconceivable Nazi crimes of mass torture, enslavement, and genocide. Imagining this violence instead in the form of rape or sexual enslavement served to "domesticate" far more unfamiliar atrocities. (p. 64)

Sexual violence, therefore, has commonly served as a way to make the Holocaust less abstract by utilising the affective power of the raped woman. In contrast with the crimes of genocide, which seemed conceptually unreachable to audiences in 1943, sexual violence possessed an emotional and cultural

3 Despite having an estimated budget of $\$ 5,000,000$, the cumulative worldwide gross of Nelson's film only amounted to $\$ 621,592$. Both domestically and internationally, therefore, it can be construed as a commercial failure with a limited impact in terms of its societal reach. It has not, it may be argued, entered the broader popular consciousness. Figures sourced from: https://www.imdb.com/title/tt0252480/. 
resonance that the public was able to engage with more readily. This trope, as Rosenfeld's statement asserts, has shown no sign of abating. The suffering female body continues to serve as a metonymic stand-in for the broader crimes of the Holocaust. ${ }^{4}$ With this in mind, therefore, Morris's representation of Cilka's sustained sexual assault at the hands of Lagerführer Schwarzhuber-and, following the release of Cilka's Journey, also Anton Taube_represents a particularly sensationalist distortion of Holocaust fact. As Wanda Witeck-Malicka has argued, the chance of a long-term "semi-explicit" relationship between a Jewish prisoner and a member of the SS within the Auschwitz camp was essentially "non-existent" (Witeck-Malicka 2018, p. 12). By contrast, Helen J. Sinnreich asserts, sexual violence in Auschwitz is commonly understood to have been more opportunistic in nature: "Several survivors of Auschwitz ... have testified that women were dragged from their barracks by guards and raped" (Sinnreich 2010, p. 111). As such, Morris's conspicuously melodramatic framing of Cilka's sexual suffering seems singularly unrepresentative of historical reality. Instead, it falls firmly within the common tropes enshrined in popular Holocaust culture. As Sarah Horowitz has argued, the horrors of the Holocaust are made comprehensible-and indeed, more resonant, for an audience unable to connect with the unreachable reality of death in the gas chamber-through Spielberg's use of the sexualised suffering of Helen Hirsch. The sequence in which Amon Goth menaces a half-naked Helen, after having chanced upon her bathing, "titillates the viewer with the suggestion that Helen Hirsch, already marked for death, will be sexually violated as well before the genocide is completed" (Horowitz 1997, p. 127). The prospect of sexual violence, therefore, arguably adds an element of domesticating drama to the generally unreachable reality of death in the gas chamber. As Barry Langford notes, the gas chamber door represents the "threshold of unrepresentability" (Langford 1999, p. 32), beyond which fiction commonly does not pass. As such, works of popular culture must instead work to find a way to make the horror of industrial mass murder more immediately accessible to a general audience. Though I do not agree with the choice of the word "titillation", as this implies an element of arousal when faced with Spielberg's evocations of Holocaust death, I nevertheless agree that popular fiction aims to promote an explicitly bodily reaction in reference to Holocaust pain. This is frequently achieved, as Spielberg's work demonstrates, through the image of the suffering woman.

This essay therefore approaches Heather Morris's two Holocaust texts from a Landsberg-inspired perspective, examining the degree to which both novels have furthered the idea that popular culture commonly chooses to engage with the Holocaust on a prosthetic level. Holocaust Impiety, or rather fictional attempts at impiety, remains the sole province of niche Holocaust fiction. Moreover, by centralising the suffering of the Cilka character, Morris has also conditioned the reader to believe that the Holocaust may be easily grasped through a bodily encounter with scenes of sexual violence. As our current understanding of Holocaust fact suggests, however, the reality was significantly more complicated than Morris's text may suggest. She has explicitly stated her desire to bring attention to the "often denied" (Morris 2019, p. 407) reality of rape in Auschwitz. However, the limitations inherent in works of Holocaust kitsch render this a relative impossibility, as the reader stands to learn nothing about the complex reality of the Holocaust past. Instead, they will engage only with inhabitable scenes of violence.

\section{Heather Morris and the Inhabitable Body}

Morris conceives of the Birkenau site not as a place defined by extermination but by omnipresent sexual violence. Though, in The Tattooist of Auschwitz, passing reference is made to the fact the characters exist in a place in which "people are dying every day, every hour, every minute" (Morris 2018, p. 33),

4 The Pawnbroker (both Edward Lewis Wallant's novel and Sidney Lumet's film) pivots around a central scene of sexual violence. Steven Spielberg's Schindler's List focuses explicitly on the sexual vulnerability of Helen Hirsch. Peter Mathiessen's In Paradise also injects an element of sexualised menace into scenes of death in the gas chamber. In terms of European texts, Jerzy Kozinski's The Painted Bird and Pascal Croci's Auschwitz also conceptualise Holocaust pain through the image of the sexually victimised female body. 
the murdered remain distant and unreachable abstractions. What Morris can reach and explore and inhabit, by contrast, is the bodily vulnerability of her female internees. The very first page of the text, in fact, seeks to emphasise the particular quality of their vulnerability. All violence against a woman within the camp setting, Morris suggests, is freighted with additional subtext: "Tattooing the arms of men is one thing; defiling the bodies of young girls is horrifying." (p. 1). "Defiling" is a weighted word, which—given the additional emphasis on gender-primes the reader for the text's particular emphasis on sexualised violence. While it can be read as a religious defilement, given the Jewish prohibition against tattoos, the text's general representation of in-camp violence clarifies Morris's meaning. She does not conceive of any Nazi-driven act as existing without a subtext of sexual menace. One must only look, for instance, at the representation of her totemic Nazis and embodying victims.

Josef Mengele, tellingly, is characterised as both an emasculator of Jewish men and a rapacious abuser of Jewish women. Morris pays particular attention to Mengele's selections, which are uniformly conveyed as leering assaults: "Mengele is examining one of the girls, roughly opening her mouth, grasping her hips, then her breasts, as tears fall silently down her face" (p. 127). Though Mengele's aim is unknowable, as it is never stated or clarified, Morris certainly presents this interaction as another defilement. The silently falling tears hint at both the girl's passivity and her trauma. She cannot actively resist but must yield to Mengele's rough groping. Morris then later heightens the trite sensationalism of this series of highly sexualised tests when Mengele insinuatingly turns to the last selected girl and states, "I'll take good care of you" (p. 128). For a modern audience well-versed in melodramatic representations of sexual assault in film and television, this phrase cannot help but carry an additional air of implied threat. The previous sequence has contextualised Mengele as a grasping, lascivious predator, and so, this phrase certainly implies the threat of further sexual violence.

Morris, therefore, clearly conceives of sexual violence as central to the Nazi design. Mengele, as a frequently invoked spectre of the horrors of the Holocaust, stands as her embodying villain - the one figure who can domesticate the crimes of the Holocaust by making them less abstract. She does not frame the event as an incomprehensibly remote industrial genocide, but as a series of direct assaults against the female body. It is Cilka, therefore, who then becomes Morris's embodying victim. The crimes of the Holocaust are most comprehensible to Morris when they are enacted upon Cilka's body.

Cilka's sexual assault at the hands of Lagerführer Schwartzhuber is detailed, using almost precisely the same text, in both The Tattooist and Cilka's Journey. The same key phrases recur in both texts, and the sequence unfolds in an almost identical fashion:

He takes off his hat and throws it across the room. With his other hand he continues to hit his leg firmly with his swagger stick. With every whack Cilka flinches, expecting to be struck. He uses the stick to push up her shirt. Realising what is expected, with shaking hands Cilka undoes the top two buttons ... She takes a step closer, still at arm's length, and begins undoing the many buttons in his jacket. A whack across her back with the stick hurries her up ... Kneeling down, she pulls his trousers down to his ankles but can't get them over his boots. (Morris 2018, p. 102)

Taking off his hat, he throws it across the room. With his other hand he continues to hit his leg firmly with his stick. With every whack Cilka flinches, expecting to be struck. He uses the stick to push up her shirt. Oh, Cilka thinks, so this is why. With shaking hands she undoes the top two buttons ... Taking a step closer, still at arm's length, she begins undoing the many buttons on his jacket. A whack across her back hurries her up ... Slowly, Cilka begins undoing his belt and the buttons beneath it. Kneeling down, she pulls his boots from over his breeches. (Morris 2019, p. 31)

Michael Fiddler and Stacey Banwell argue that works of low-art-in this instance referring to films within the subgenres of exploitation and Nazisploitation—are characterised by "excesses of corporeality 
on screen as well as in spectatorial experience" (Fiddler and Banwell 2019, p. 150). ${ }^{5}$ Just as these films focus excessively on bodily suffering, with a particular emphasis on women's sexualized pain, so too might Morris's representations of violence be deemed almost excessively corporeal. ${ }^{6}$ Every second preceding Cilka's rape is minutely choreographed. Instead of describing it with her characteristic vagueness, Morris truly inhabits the sequence. Just as Marlin Lax was able to form a felt connection to the Mauthausen camp through scenes of physical suffering, so too has Morris found a point of access to the Holocaust past through Cilka's pain. She emphasises the materiality of the clothing and minutely details every gesture. While this is perhaps more explicit in The Tattooist, which takes additional pains to highlight the fact that Schwarzhuber's "nostrils distend" (Morris 2018, p. 102) as he breathes heavily, both texts clearly physicalise this assault. They both emphasise the "whack" of the riding crop as a means to stress the undercurrent of brutality in Schwarzhuber's sexual advances and the laborious specifics of undressing. In short, it is only within this kind of sequence-one that stresses the material reality of sexual threat-that Morris's writing comes alive. In place of the faceless victims dying every day, hour or minute in unknowable parts of the camp, Morris may access this moment of horror and give it texture in the form detail. Her emphasis on buttons, belts, hats, boots, singlets and gestures is profoundly telling, as it reveals that this is the one space in which she can engage both cognitively and bodily. Morris, in effect, has created her own "prosthetic memory". In contrast with Holocaust Impiety, which is concerned with psychological proximity to the victim, Landsberg's theory is concerned with the viewer/reader's felt proximity to a body in pain. She illustrates this with reference to the death of the hinge-maker in Schindler's List: "Our closeness to him, our mimetically induced relationship to him-makes us feel vulnerable in bodily ways, which makes us cringe and wriggle in our seats" (Landsberg 2004, p. 126). Landsberg is referring to the camera's literal nearness to the victim, the "overpresence" (p. 126) of his face on screen, which allows the viewer to focus on the minute details of his suffering. In a similar sense, therefore, the material reality of Cilka's rape is conspicuously over-present, as we have been made unsettlingly familiar with the minute details of her assault. The second-by-second itemisation has a certain relentlessness that ensures that we are hyper-aware of both Cilka's bodily vulnerability and Schwarzhuber's actions. Morris, therefore, has positioned both the reader and herself in close proximity to the scene, explicitly fostering identification with Cilka on a purely physical level. As she is not characterised in The Tattooist, crucially, this is the only manner in which we can engage with her. She does not speak, and she is described simply as "a young woman unaware of her own beauty and seemingly untouched by the world around her" (Morris 2018, p. 89). As such, she exists simply as a body primed for prosthetic engagement. As Landsberg has argued, audiences tend to revolt when presented with bodies that are too unlike their own. As such, given her explicit reliance on the bodily, Morris needs a character who will remain either entirely unquantified or consistently uncomplicated in order to maintain her felt connection to the Shoah. This requirement, I contend, destroys any hope of complex character development, and therefore an informative engagement with the Holocaust past, in Cilka's Journey. While Morris clearly wishes to enlighten the public as to the nature of wartime sexual assault, the mode in which she is writing-melodramatic Holocaust kitsch-effectively invalidates the attempt.

5 It should be noted that the featured phrase "excesses of corporeality on screen as well as in spectatorial experience" is actually sourced from Mark Betz. In the original source, however, Betz does not use it exclusively in the context of low-art but, instead, suggests that it also typifies the genre-bending "New Extremist" (Betz 2013, p. 505) cinema that began emerging in the 1990s and has continued into the present. These generally European (often French) and Eastern-European films are defined by their particularly lurid depictions of sex and violence.

6 Fiddler and Banwell note that, as a genre, Nazispolitation films tend to view "Nazism's horrors" through an "eroticised lens" (Fiddler and Banwell 2019, p. 145). While Sergio Garrone's SS Lager 5: L'inferno Delle Donne (1976) physicalises the suffering of women through scenes of medical experimentation, forced prostitution and rape, Don Edmond's Ilsa: She-wolf of the SS (1975) broadly limits itself to scenes of sexualised medical experimentation. Both, it may be said, place excessive emphasis on the physicalisation of women's suffering. To this general trend, we may also add SS Experiment Camp (1976), Love Camp 7 (1969) and The Gestapo's Last Orgy (1977). 


\section{Corporeality and Morality in Cilka's Journey}

In the endnote that accompanies Cilka's Journey, Morris states that she uncovered "conflicting comments" regarding Cilka's behaviour within the camp: "she did bad things to survive; she gave me extra rations when she found I came from the same town as her; she yelled and screamed at the condemned women; she smuggled me food when I was certain I would die of hunger" (Morris 2019, p. 404). This series of conflicting reports would seem to lay the foundations for an impious portrait of one firmly entrenched within Levi's "grey zone" of forced complicity. Specifically outlining the role of privileged prisoners - a group that would also unquestionably include Cilka as a block leader-Levi notes:

It is naïve, absurd and historically false to believe that an infernal system such as National Socialism was, sanctifies its victims: on the contrary, it degrades them, it makes them similar to itself, and this all the more when they are available, blank, and lack a political or moral armature. (Levi 2009, p. 25). ${ }^{7}$

A commendable piece of fiction, therefore, would surely account for the moral complexity of Cilka's position. It may attempt, using other anterior sources as a point of inspiration, to represent the emotional reality of wartime sexual compromise with a degree of impiety. The historical note that accompanies Cilka's Journey, provided by Owen Mathews, explicitly references the "essential selfishness of human suffering" (Morris 2019, p. 421). An informative recounting of the event, therefore, would aim to present a picture of Cilka that is equally contradictory-interspersing her rational selfishness, which may be repellent to modern audiences, with specific instances of compassion. This, after all, would align with previous presentations of other subsets of privileged prisoners within the camp. The Sonderkommando, for instance, are described by Miklós Nyiszli as regularly performing charitable actions without partiality: "The Sonderkommando was an elite group; its advantages and privileges have already been noted ... Fully aware of this unbalanced situation, the Sonderkommando distributed food and clothing to their less fortunate comrades whenever they could" (Nyiszli 2012, p. 50). These examples of charity stand as a conceptual counterpoint to their participation in the extermination process-from the undressing and pacifying of prisoners prior to their gassing to the eventual disposal of their bodies. While these actions induced an unquestionable level of psychic pain-Nyiszli notes that they had a "general tendency towards "nervous disorder", given the "tremendous strain" of processing "thousands of corpses" (p. 45) on a daily basis-the fact remains that the Sonderkommando were still driven by an innately human desire to survive. By contrast, Cilka is not presented with this level of depth. Instead, Morris paints her as possessing a faultless, uncontaminated, unyielding decency. When faced with the bodies of the dead in Auschwitz, for instance, she is not callous but strangely reverent:

One of them has died and is lying on a top bunk. Cilka climbs up to her, and as gently as she can, lowers her down into the arms of two waiting women ... Cilka climbs down and helps properly place her across their spindly arms, then adjusts the woman's meagre clothing to give her a degree of dignity in death. (Morris 2019, p. 135)

This exaggerated display of compassion contrasts starkly with the view of the body portrayed by those who lived to write survivor texts. Holocaust survivor Sara Nomberg-Przytyk, for instance, has previously discussed the treatment of bodies within Auschwitz, noting:

7 Privileged prisoners are those within the camp system who came to occupy positions that afforded either a degree of protection or power. The "top of the pecking order" (Cesarani 2016, p. 657) within the camp hierarchy, as David Cesarani notes, was the kapo. Placed in charge of "sections of the camps, blocks and commandos", these men and women enjoyed a relatively "cushioned existence" (p. 657) within the camp setting. The Sonderkommando, given their superior access to food and supplies, would also fall under this umbrella term. 
Every morning the sztunowa pulled dead women out of the beds. She immediately stripped them naked, dragged them through the whole block, and heaved them into the mud ... I was frightened that tomorrow they would be dragging me through the block, a nameless dishonoured corpse, unmourned by anyone. (Nomberg-Przytyk 1985, p. 22)

The dead of Auschwitz, therefore, were not treated with reverential care but, rather, were cast out into the mud "dishonoured" and "unmourned" by their fellow internees. By emphasising Cilka's concern for the modesty of the corpse, Morris is reiterating to the reader that she is still approachable and inhabitable. Were she to complicate Cilka's presentation, by showing her learned callousness or her Auschwitz-specific morality, it would block our attempts to bodily identify with her suffering.

Further evidence of this can also be found in the portrayal of Cilka's role as a block leader, as, rather than brutalising her fellow prisoners-showing a learned disdain for their passivity-she is shown to be consistently conciliatory and kind. In a sequence in which the women of Cilka's block are being forced onto trucks prior to being gassed, Morris stresses Cilka's attempt to minimise their pain:

The last woman is struggling to walk ... Cilka sees the nearest SS officer pull his swagger stick from its holder on his belt and advance on the woman. Cilka gets to her first, screaming at her as she slips her arm around the woman, half-dragging her towards the truck. The SS officer puts his stick away. (Morris 2019, p. 364 )

Morris, therefore, has resolved her inner quandary regarding the discovery that Cilka "did bad things in order to survive" and "screamed at the condemned women" by choosing to portray all of her more dubious behaviours as purely performative. Cilka has not, according to this portrayal, ever acted out of malice or been inculcated into the brutality of the camp. Her every violent action is instead couched in noble intentions. ${ }^{8}$ This is, once again, radically different from the documented reality of the morality of the privileged-both within the concentrationary system and the ghettos. Nyiszli, for instance, also speaks disdainfully of the passivity of those being undressed by the Sonderkommando, noting: "their dignity rebelled; but, with the resignation particular to their race ... they slowly began to undress" (Nyiszli 2012, p. 28). Nyiszli, in using the word "their", implicitly scorns the group's lack of resistance and signals his desire to class himself as a separate kind of Jewish victim. Similarly, Calel Perechodnik describes the inherent selfishness of those operating within the Jewish ghetto police: "They take over the apartments of strangers after telling the people to get out, ordering them to leave all of their possessions behind. They themselves hoard in these apartments extensive wealth. They drink, rob and fulfil the orders of the Germans" (Perechodnik 1996, p. 17). There is no nobility or selflessness in this presentation but, rather, the simple, acquisitive greed of those looking to survive. The privileged, once again, seek to distinguish themselves from those doomed to die-who are automatically devalued as humans. As Perechodnik highlights, the morality of the ghetto is defined by unitary self-interest, which leaves no room for equivocations regarding everyone outwith one's own family unit: "Here everyone is condemned to death. But no one knows that. What won't a Jew do to live an hour longer?" (p. 39). The ghetto police Lieutenant (Kronenberg), he notes, did not give up his own wife during an action and yet told his subordinates to "provide theirs" (p. 39) for transportation. This perfectly illustrates the general lack of human regard felt for all those beyond oneself within the ghetto system. While moral exceptions certainly existed, Perechodnik illustrates that the particular morality of the ghetto effectively precluded compassion. People would do anything to ensure their own survival, irrespective of the cost to others. This morally complex portrayal of people driven by an animalistic instinct "for self-preservation" (p. 74) therefore possesses a human authenticity that is singularly lacking from Morris's depiction. Perechodnik, as a member of the Jewish police who consigned his fellow Jews

8 Further evidence of this can also be found in an earlier sequence in which Cilka apologetically states the following to four women: "They would have stuck their rifles in your belly and dragged you back here if I didn't say something first" (Morris 2019, p.135). Tellingly, the four women then "nod", "understanding" (p. 135) that Cilka's inner desire is to avoid any undue pain for her charges. Her seeming cruelty, they realise, is calculated to minimise their suffering. 
to their deaths, is speaking from a position of genuine knowing. Moreover, as Perechodnik's text represented one of the "confessional diaries" recovered after the events of the Holocaust-texts that were written in the fall of 1943, at a point in time at which any Jewish individual "still alive" in the "Jew-Zone" represented a "statistical error" (Roskies and Diamant 2012, p. 69)_it possesses a degree of honesty and insight that is rare even among the subgenre of ghetto diaries. Those still alive at that point in time commonly had a "terrible secret to confess" (p. 69), having survived at the expense of their fellow Jews. While, theoretically, anterior sources do therefore exist that could have provided the necessary moral detail to impiously represent wartime sexual compromise, Morris remains trapped within the confines of Holocaust kitsch. Given her commitment to popular fiction and prosthetic memory, she can only provide a morally reductive portrait of Cilka as a secular saint.

In her essay discussing the moral complexity of sexual bartering within the Theresienstadt ghetto, Anna Hájková notes that a "predicament" commonly emerges when discussing issues relating to "gender and the Holocaust". Specifically, she claims, it is often difficult to discuss these matters "without making moral judgements" (Hájková 2013, p. 505). One must consider this when pondering the fact that Heather Morris has consciously framed Cilka's Journey as a tool to raise awareness of Holocaust sexual violence:

Time is up. It is time these crimes of rape and sexual abuse were called out for what they were. Crimes often denied as they were not part of 'official Nazi policy' ... To deny it happened is to stick your head in the sand. (Morris 2019, p. 407)

While her intent may seem noble- to ignore the specific suffering of women throughout the Holocaust is to foundationally limit our understanding of the event-I contend that Morris has singularly failed to convey the broader reality of sexual violence during the Shoah. She has not brought greater attention to the crimes of rape and sexual abuse but has merely perpetuated a morally reductive understanding of sexual violence. Popular culture often struggles to avoid an element of reflexive judgement when framing instances of wartime sexual assault, as there is an enduring assumption that suicide is "the acceptable face of women's agency" (Gedalof 1999, p. 35) when faced with the prospect of rape. Though this is perhaps more overt in Israeli Holocaust fiction, which has previously framed wartime rape as a form of contamination that comes to infect subsequent generations, Morris's conspicuously moral framing of Cilka's assault also suggests that this tendency exists within Anglo-American popular culture. ${ }^{9}$ As Morris's novels strive to create a felt connection with the Holocaust past-by generating instances of sexual violence that can be engaged with on a prosthetic level-they cannot portray their featured characters with a degree of moral complexity. This, as Landsberg previously asserted, would block the reader's attempts to inhabit Cilka's body. Cilka must be portrayed, like Oskar Schindler, as a reductively decent character, as this provides the means to inhabit her subject position. This desire to shape Cilka into an ideal figure for prosthetic engagement is evident not merely in Morris's frequent attempts to exonerate her of any perceived wrongdoing, but also in her desire to frame her rape as a form of self-sacrifice.

In the sequence in which Cilka effectively saves Lale's life-arguably the defining moment of Cilka's narrative-Morris chooses to emphasise the tragic nobility of Cilka's choice. Schwarzhuber does not see the tears that she wipes from her eyes "as she tells the biggest lie of her life" (Morris 2019, p. 352)-that she cares for him on a personal level. This is automatically contextualised as being both shameful and personally painful. Morris, therefore, is establishing the personal cost of this transaction-a price that

9 As Sandra Meiri has noted, early Holocaust-themed Israeli cinema (1947-1960) commonly portrayed female survivors as former forced prostitutes who then eventually become "unfit mothers and/or mental patients" (Meiri 2015, p. 445). After this point, the emphasis shifted away from the female survivor towards their psycho-sexual impact on subsequent generations. The fictional emphasis then took the form of a taint of sexual corruption passed on from survivors to the subsequent generations, who had grown up "living in the shadow of women's trauma" (p. 453). This shadow profoundly warps and corrupts the sexual impulses of all future generations leading to a series of sexual aberrations. Evidence of this latter trend can be found in Burning Mooki (2008), Intimate Grammar (2010) and the Israeli-American coproduction Death in Love (2008). 
will be weighed against Lale's survival. While she does inject a brief moment of self-interest into this sequence-she notes that this lie will "allow" Cilka "to stay alive" (p. 352)—any pretence of selfishness is immediately abandoned as Cilka begins to plead on Lale's behalf. "I've never asked you for anything in all the time we've been together" (p. 352), she notes. This request is therefore immediately contextualised as the one redemptive action that will define her relationship with Schwarzhuber. Moreover, it also recontextualises her statement that she has feelings for him. This is no longer an expression of self-interest, but the actions of a noble manipulator priming her oppressor for a coming request. She will concede to his desires, but only so that another may stand a greater chance of survival. The emotional cost of this transaction is then emphasised in the final lines of the scene, as Morris notes: "Cilka clears her throat and swallows back her tears. There is no use for them in a place like this" (p. 353). There is once again an implicit moralism in this statement as Morris wishes to emphasise that Cilka is not revelling in her powers. She is not lascivious, practiced or coldly calculating, but rather, she is as moral and susceptible to shame as any woman in the civilised world. In emphasising the cost, Morris constantly reiterates to the reader that Cilka is not a morally complex woman operating in the grey zone, but rather, she is simply a martyr. This is not an accurate reflection of what Kerstin Steitz calls "the complexities of the conditions and relationships in the camps and ghettos during the Holocaust" (Steitz 2017, pp. 120-21). Refencing the 1965 film Zeugin aus der Hölle, one of the few available works of Holocaust fiction to address the theme of sexual violence with a degree of complexity, Steitz notes that it uniquely highlights the protagonist's selfish desire to survive. Lea Weiss (played by Irene Papas) refuses to feel guilty for her own survival and, in her own defence, asserts simply, "Back then I was a human being. A young woman, who was ready to suffer anything to stay alive" (p. 119). In taking this stance of shamelessness, this refusal to concede that survival is an insufficient motive for having lived through wartime rape, Weiss is rejecting the "misogynist discourse" that assumes that the rape victim is "guilty and tainted" (p. 119). By contrast, Morris's pious representation of Cilka's narrative is arguably both indirectly misogynistic and reductive, as her tendency to overemphasise Cilka's decency tacitly endorses the notion that wartime sexual compromise should carry an element of guilt. One cannot simply have lived, her text asserts, as this would be selfish and ignoble. Instead, one must have lived for a reason - their sexual compromise having served a broader, ultimately redemptive purpose. Her text, therefore, cannot possibly hope to raise awareness of wartime sexual violence, as every instance in which it is cited comes with an element of moral embellishment. This is not a reflection of the past but, rather, an overly moralistic reinterpretation of Holocaust fact-one that bears no relation to the documented historical reality of wartime sexual violence. Prosthetic memory, given its need to morally simplify the matter at hand, cannot provide a worthwhile insight into the Holocaust past.

\section{Conclusions}

According to Boswell's aforementioned definition of Holocaust Impiety, Morris did theoretically have the tools in hand to provide an impious reading of Cilka's wartime sexual compromise. While few written sources provide first-hand accounts of sexual assault, anterior sources do exist that depict the reality of life within the grey zone. This additional psychological detailing could have provided an impious glimpse into her sex-for-survival dynamic. However, Morris's text cannot escape from the confines of Holocaust kitsch and, ultimately, Holocaust Piety. Much like John Boyne and Steven Spielberg, Morris has aimed to create a work of popular Holocaust fiction-one that seeks to provide an easy point of access into the horrors of the Holocaust. She is not looking to challenge her audience's conception of the atrocity, to provide them with an impious glimpse into life within Auschwitz, but to simply provide them with a felt-and indeed emotive-connection to the Holocaust. As such, the event can only be represented in the form of a prosthetic memory-an inhabitable moment of pain, in this instance taking the form of scenes of sexual violence. Cilka's pain, in short, becomes Morris's primary means of accessing the horror of the Holocaust-particularly as no other scenes of suffering are provided. However, prosthetic memory can communicate nothing to the modern reader or viewer beyond the brute fact of bodily pain. As we cannot inhabit a body that possesses a distinct 
personality or that has been culturally particularized, we cannot engage with the psychological reality of wartime suffering. An impious presentation of Cilka's plight-one that factored in the particular moral reality of life within the concentration camp or the ghetto-would allow for the production of more representative, less inherently judgemental texts. A continued focus on the suffering body results only in the replication of the culturally ingrained prejudices that still seem to dog Holocaust fiction. Morris's writing is tangible proof, above all else, of the moral reductivism that can still shape the popular presentation of sensitive subjects.

Funding: This research received no external funding.

Conflicts of Interest: The author declares no conflict of interest.

\section{References}

Betz, Mark. 2013. High and low and in between. Screen 54: 495-513. [CrossRef]

Bos, Pascale R. 2014. 'Her Flesh is Branded: "For Officers Only"': Imagining and Imagined Sexual Violence Against Jewish Women During the Holocaust. In Lessons and Legacies XI: Expanding Perspectives on the Holocaust in a Changing World. Edited by Hilary Earl and Karl A. Schleunes. Evanston: Northwestern University Press, pp. 59-85.

Boswell, Matthew. 2012. Holocaust Impiety in Literature, Popular Music and Film. Basingstoke: Palgrave Macmillan. Boyne, John. 2008. The Boy in the Striped Pyjamas. London: Random House.

Cesarani, David. 2016. Final Solution: The Fate of the Jews: 1933-49. London: Macmillan.

Cowdrey, Katherine. 2018. Tattooist of Auschwitz to be adapted for "high-end" TV drama. The Bookseller. Available online: https://www.thebookseller.com/news/tattooist-auschwitz-be-adapted-high-end-tv-drama-867181 (accessed on 19 September 2018).

Eaglestone, Robert. 2017. The Broken Voice: Reading Post-Holocaust Literature. New York: Oxford University Press USA.

Fiddler, Michael, and Stacy Banwell. 2019. 'Forget all about your taboos': Transgressive memory and Nazisploitation. Studies in European Cinema 16: 141-54. [CrossRef]

Gedalof, Irene. 1999. Against Purity: Rethinking Identity with Indian and Western Feminisms. London and New York: Routledge.

Hájková, Anna. 2013. Sexual Barter in Times of Genocide: Negotiating the Sexual Economy of the Theresienstadt Ghetto. Signs: Journal of Women in Culture and Society 38: 503-33. [CrossRef]

Horowitz, Sara R. 1997. But is it Good for the Jews? Spielberg's Schindler and the Aesthetics of Atrocity. In Spielberg's Holocaust: Critical Perspectives on Schindler's List. Edited by Yosefa Loshitzky. Bloomington: Indiana University Press, pp. 119-39.

Kertész, Imre. 2001. Who Owns Auschwitz? The Yale Journal of Criticism 4: 267-72. [CrossRef]

Landsberg, Alison. 2004. Prosthetic Memory: The Transformation of American Remembrance in the Age of Mass Culture. New York and Chichester: Columbia University Press.

Langford, Barry. 1999. "You Cannot Look at This": Thresholds of Unrepresentability in Holocaust Film. The Journal of Holocaust Education 8: 23-40. [CrossRef]

Levi, Primo. 2009. The Drowned and the Saved. Translated by Rosenthal. London: Abacus. First published 1986.

Littell, Jonathan. 2010. The Kindly Ones. London: Vintage.

Mansfield, Katie. 2019. Tattooist of Auschwitz Hits Million Copy Milestone. The Bookseller. Available online: https://www.thebookseller.com/news/tattooist-auschwitz-hits-million-copy-milestone-1103901 (accessed on 24 October 2019).

Meiri, Sandra. 2015. Visual responses: Women's experience of sexual violence as represented in Israeli Holocaust-related cinema. European Journal of Women's Studies 22: 443-56. [CrossRef]

Morris, Heather. 2018. The Tattooist of Auschwitz. London: Zaffre Publishing.

Morris, Heather. 2019. Cilka's Journey. London: Zaffre Publishing.

Nomberg-Przytyk, Sara. 1985. Auschwitz: True Tales from a Grotesque Land. Translated by R. Hirsch. Chapel Hill and London: The University of North Carolina Press.

Nyiszli, Miklos. 2012. Auschwitz: A Doctor's Eyewitness Account. Translated by T. Kremer, and R. Seaver. London: Penguin Classics. First published 1960. 
Perechodnik, Calel. 1996. Am I a Murderer: Testament of a Jewish Policeman. Translated by F. Fox. Boulder: Westview Press Inc. First published 1993.

Rose, Gillian. 1996. Mourning Becomes the Law. Cambridge: Cambridge University Press.

Rosenfeld, A.H. 1988. A Double Dying: Reflections on Holocaust Literature. Bloomington and Indianapolis: Indiana University Press.

Roskies, David G., and Naomi Diamant. 2012. Holocaust Literature: A History and Guide. Hanover: Brandeis University Press.

Rothe, Anne. 2011. Popular Trauma Culture: Selling the Pain of Others in the Mass Media. New Brunswick and London: Rutgers University Press.

Sinnreich, Helene J. 2010. The Rape of Jewish Women during the Holocaust. In Sexual Violence against Jewish Women during the Holocaust. Edited by S.M. Hedgepth and R.G. Saidel. Hannover: Brandeis University Press, pp. 108-23.

Steitz, Kerstin. 2017. No "Innocent Victim"? Sexual Violence against Jewish Women during the Holocaust as Trope in Zeugin aus der Hölle. Women in German Yearbook 33: 101-27. [CrossRef]

Vice, Sue. 2000. Holocaust Fiction. London and New York: Routledge.

Weissman, Gary. 2004. Fantasies of Witnessing: Postwar Efforts to Experience the Holocaust. Ithaca and London: Cornell University Press.

Witeck-Malicka, W. 2018. Fact Checking the Tattooist of Auschwitz. Memoria 14: 6-17. Available online: https: //view.joomag.com/memoria-en-no-14-11-2018/0766192001543510530/p6?short (accessed on 6 February 2019).

(C) 2019 by the author. Licensee MDPI, Basel, Switzerland. This article is an open access article distributed under the terms and conditions of the Creative Commons Attribution (CC BY) license (http://creativecommons.org/licenses/by/4.0/). 